\title{
Histopathological changes associated with exposure of some viscerals and testicular tissues to bisephenol $A$ and di(2-ethylhexyl)phthalate
}

\author{
Nosa Terry Omorodion, ${ }^{1,3}$, Blessing Emosho Atoigwe-Ogeyemhe ${ }^{2,3}$, Peter \\ Uwadiegwu Achukwu², Efosa Bolaji Odigie ${ }^{3}$ \\ ${ }^{1}$ Health Services Department, University of Benin, Ugbowo, Benin City 300001, ${ }^{2}$ Department of Medical Laboratory, Faculty of \\ Health Sciences and Technology, University of Nigeria, Enugu Campus, Enugu, ${ }^{3}$ Department of Medical Laboratory Sciences, \\ Faculty of Basic Medical Sciences, College of Medicine, University of Benin, Benin City 300001, Nigeria
}

${ }^{*}$ For correspondence: Email: terry.omorodion@uniben.edu; Tel: +234-8136742270

Sent for review: 1 November 2019

Revised accepted: 22 May 2019

\begin{abstract}
Purpose: To evaluate the pathological effect associated with the exposure of viscerals and testicular tissues of albino rats to BPA and DEHP.

Methods: A total of sixty adult male Wistar rats weighing $200-250 \mathrm{~g}$ were divided into four (4) groups of 15 rats per cage in a sanitized environment. Group I animals received normal rodent pellet and water and served as untreated group. Thereafter, the rats in the second group (II) were administered $5 \mathrm{mg} / \mathrm{kg}$ per day of BPA mixed with rodent pellet orally; group III received $0.5 \mathrm{mg} / \mathrm{kg}$ daily dose of DEHP mixed with rodent pellet; while group IV received orally mixture of $0.5 \mathrm{mg} / \mathrm{kg}$ of BPA and $0.5 \mathrm{mg} / \mathrm{kg} D E H P+$ pelleted rodent feed. The rats were fed and water provided regularly for 30 days; finally, the animals were weighed and sacrificed by cranial dislocation.

Result: BPA and DEHP resulted in significant $(p<0.05)$ weight losses, inflammation and fatty deposits in the liver, degenerated bowman capsule and glomeruli of the kidneys, lung oedema, and deteriorated leydig cells in testes.

Conclusion: The results suggest that BPA and DEHP cause significant weight loss and are injurious to the cellular make-up of rat tissues, which may be the same in higher animals.
\end{abstract}

Keywords: Bisphenol A, Di (2-Ethylhexyl) phthalate, Testicular tissues and Viscerals

\begin{abstract}
This is an Open Access article that uses a fund-ing model which does not charge readers or their institutions for access and distributed under the terms of the Creative Commons Attribution License (http://creativecommons.org/licenses/by/4.0) and the Budapest Open Access Initiative (http://www.budapestopenaccessinitiative.org/read), which permit unrestricted use, distribution, and reproduction in any medium, provided the original work is properly credited.
\end{abstract}

Tropical Journal of Pharmaceutical Research is indexed by Science Citation Index (SciSearch), Scopus, International Pharmaceutical Abstract, Chemical Abstracts, Embase, Index Copernicus, EBSCO, African Index Medicus, JournalSeek, Journal Citation Reports/Science Edition, Directory of Open Access Journals (DOAJ), African Journal Online, Bioline International, Open-J-Gate and Pharmacy Abstracts

\section{INTRODUCTION}

$\mathrm{Di}$ (2-ethyhexyl)phthalate (DEHP) and Bisephenol A (BPA) broadly occur in plastic and constant introduction to human body, which happens through dietary means by way of indiscriminate consumption, inward breathing, dermal and intravenous route by means of consumer products and medical devices is worrisome. Effect of BPA on adipose tissue in a study showed clashing and difficult to translate information in all probability due to broad scope in the dosage given. Buildup of Bisephenol A in rodent fatty tissues was low in a study [1] however high result was obtained in another [2]. It was reported that Bisephenol A when 
administered to rats in an increased doses and for a short duration (15 days) indicated an enormous decrease in weight of animals in addition to a reduced appetite and cravenness [2]. In contrast from the foregoing, a finding revealed that chronic BPA administration to rats for 3 months did not bring about a change in body weight, fat storage or a rise in triglyceride level [3]. It was also revealed that by utilizing 3T3-F442A, adipocytes and BPA invigorated insulin-dependent glucose uptake with augmented Glut4 expression in an animal model [4-6].

Di (2-ethylhexyl) phthalate (DEHP) is majorly utilized as a plasticizer of polyvinyl chloride (PVC) in assembling wide quantities of consumer products for structural engineering works, autos, dresses, toys and therapeutic gadgets [7]. Di (2ethylhexyl)phthalate (DEHP) was categorized under the Non-deleterious Drinking Water and Toxic Enforcement Act of 1986 (generally known as Proposition 65, classified at Health and Safety Code Section 25249.5 et seq.), which is known to the state to cause reproductive lethality (formative and male reproductive injurious effects), effective October 24, 2003 [8]. This situation hinged on a proper identification of DEHP as being instrumental to varieties of developmental and male reproductive defects following the order of the National Institute for Occupational Safety and Health [8]. There is no acclaimed and composed focus where these plastic risks are described, in Enugu, Nigeria, in these way uncovering individuals from the overall population to the plastic bio-hazards. The need to guarantee that the plastic items we use does not contain risky synthetic substances that presents as danger to our body tissues and organs, prompted our examining the impacts of these chemical substances (BPA and DEHP) on some organs and testicular tissues of Wistar rats.

\section{EXPERIMENTAL}

A total of 60 male adult Wistar rats weighing between $200-250 \mathrm{~g}$ were purchased from animal house, University of Nigeria, Enugu Campus.

\section{Ethical consideration}

The study commenced after obtaining ethical approval from College of Medicine Ethics Committee (COMREC) and assigned with approval no. 076/2018.

\section{Acute toxicity study}

Acute toxicity study was conducted in accordance to standard Lorke's method [9]. The median lethal dose $\left(\mathrm{LD}_{50}\right)$ was calculated using the formula: " $L D_{50}=\sqrt{ }$ (Highest nonlethal dose) $x$ (Lowest lethal dose) [9]. The $\mathrm{LD}_{50}$ is a possible dose to which an animal could be exposed at one time and may serve as fundamentals for test doses.

\section{Histopathological studies}

Four groups of 15 rats each per cage (labeled I IV) were used to divide the animals. Animals were granted unrestricted access to standard pelleted rat's feeds including pyrogen-free water, which was obtained commercially. Both test and control rats were weighed prior to experimentation. Experimental groups II, III and IV were on daily treatment by BPA and DEHP combined with rodent pellet and were given to animals morning and evening using the results of the acute toxicity test as a gold standard.

Animals in group I received normal rodent pellet and water and served as untreated otherwise seen as control. Group II was administered 5 $\mathrm{mg} / \mathrm{kg} /$ day of BPA mixed with rodent pellet orally, group III was administered $0.5 \mathrm{mg} / \mathrm{kg}$ daily dose of DEHP mixed with rodent pellet while group IV received orally mixture of $0.5 \mathrm{mg} / \mathrm{kg}$ of BPA and $0.5 \mathrm{mg} / \mathrm{kg}$ DEHP + pelleted rodent feed. The rats were fed regularly for 30 days and on completion of the testing, treated rats were weighed, and sacrificed by cranial dislocation. The liver, kidney, GIT, Lungs, heart and testicular tissues were harvested, fixed, processed, embedded, sectioned and stained with $H / E$ and Immunohistochemistry for assessing cellular proliferation and degeneration of cells.

\section{Fixation of tissue}

Transverse and longitudinal sections of the tissues were taken and immersed in copious volume of $10 \%$ formal saline [10].

\section{Processing of tissues}

The tissues were taken to the laboratory where specific sites which shows evidence of discoloration or Necrosis (grossing) were taken and processed using the automatic tissue processor [10,11].

\section{H\&E staining protocol}

Labeled sections for H\&E were adequately dewaxed and hydrated. Slides were stained with haematoxylin, rinsed with scot's water and differentiated using $1 \%$ acid-alcohol. It was again, rinsed in another batch of water, blued properly in running tap water and counterstained 
in $1 \%$ eosin, while stained sections were then dehydrated, xylene cleraed and DPX mounted $[10,11]$.

\section{IHC staining protocol}

Slides were rinsed in phosphate buffer saline (PBS) (Genemed, USA); after that, sections were incubated with mouse plus rabbit linker and with horseradish peroxidase (Genemed, USA) for 15 minutes each followed by 2 washes at 2 minutes each. Development of chromogen was allowed for 5 minutes with 3, 3'-diaminobenzidine hydrochloride (DAB) mixed equally with its substrate solution (Genemed, USA). Each slide was counterstained with haematoxylin (Jallica Scientific, Zaria), drained and mounted with DPX [10].

\section{Microscopy and photomicrography}

Slides were examined using Swift Binocular Microscope with an Olympus photomicroscope $\AA$ (Opticshot- 2; Nikon, Tokyo, Japan) at x40 magnification.

\section{Statistical analysis}

The data collected were subjected to one-way analysis of variance (ANOVA) followed by Dunnett's multiple comparison test, with the aid of SPSS (version 25.0). $P<0.05$ was considered statistically significant.

\section{RESULTS}

\section{Weight}

Significant weight loss $(p<0.05)$ was observed in groups (II, III, IV) that were treated, which was compared with the control group (I) as shown in Table 1.

\section{Histopathological features of tissues}

In liver tissues, there were fatty deposits and inflammatory cells found in rats treated with BPA, DEHP and BPA+DEHP (group II, III and IV) in comparison with untreated slide (Figure 1). Lung tissues showed infiltrated cells within the alveoli and were evident with presence of neutrophils, lymphocytes and edema (swellings) within the alveoli and interstitium in the treatment groups (II, III and IV) (Figure 4). However, epithelia cells and villi of the intestine appeared normal in the treated groups (II, III, IV) showing the same appearance as the untreated group I (Figure 2). In the kidney tissues, rats treated groups (II, III and IV) showed a reduction in bowman capsules and glomeruli in comparison with control group
(Figure 3). In the heart tissues, there were no cellular changes observed in animals on treatment (groups- II, III and IV) in relation with untreated rats in group I (Figure 5). In the testicular tissues, there is a reduction of the leydig cells in treated groups (II, III and IV) compared to animals that are not on treatment (Figure 6). For immunohistochemistry analysis, this study showed no observable increase in Ki67 activities (Figure 7).

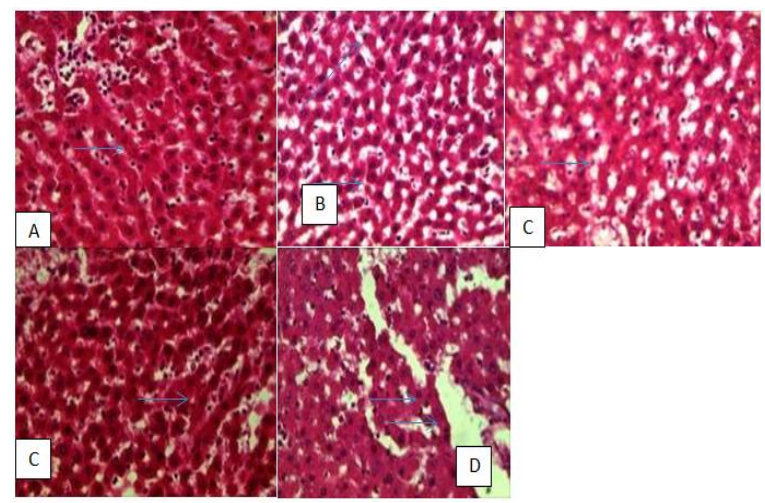

Figure 1: Photomicrograph of liver tissue showing control (A), rats treated with $5 \mathrm{mg} /$ feed BPA + rat pellet with water/day, shows fatty deposit and inflammation of the hepatocyte (B) (arrows), rats treated with $0.5 \mathrm{mg} / \mathrm{kg}$ DEHP + rat pellet / water daily, reveals fatty deposit in the hepatocyte and inflammation (C) (arrows). Rats treated with pellet + $0.5 \mathrm{mg} /$ feed BPA + 500 $\mu \mathrm{g}$ DEHP / feed daily water shows fatty deposit and inflammation of the hepatocyte (D)

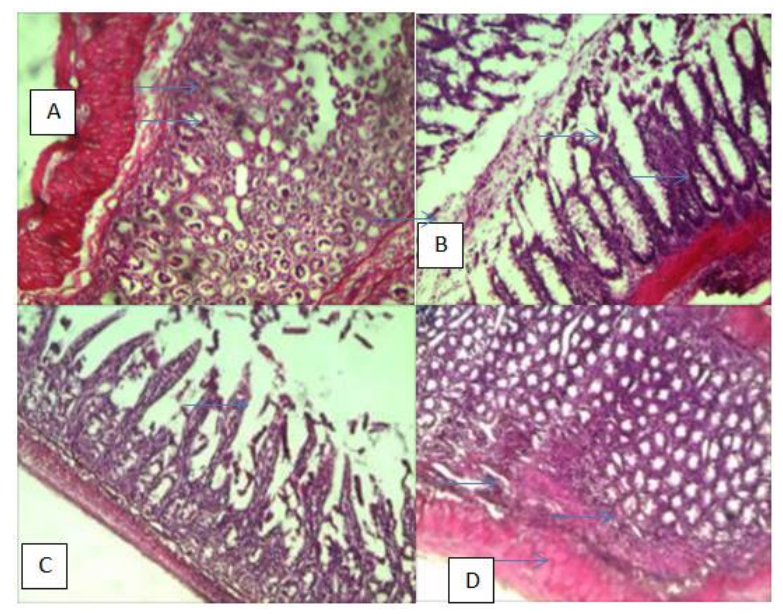

Figure 2: Photomicrograph of intestine tissues showing control with normal cellular architectures (A), rats treated with $5 \mathrm{mg} /$ feed BPA + pelleted rat feed+ water daily $(B)$ with normal cellular architecture as control, rats treated with $0.5 \mathrm{mg} / \mathrm{kg}$ DEHP + pelleted rat feed + water/day $(C)$ and rats treated with $0.5 \mathrm{mg} / \mathrm{kg}$ $\mathrm{BPA}+500 \mu \mathrm{g} / \mathrm{kg} \mathrm{DEHP}+$ water/daily (D) also shows similarity with the control. stain H\&E; X400mag. The villi and globlet cells are histologically normal 


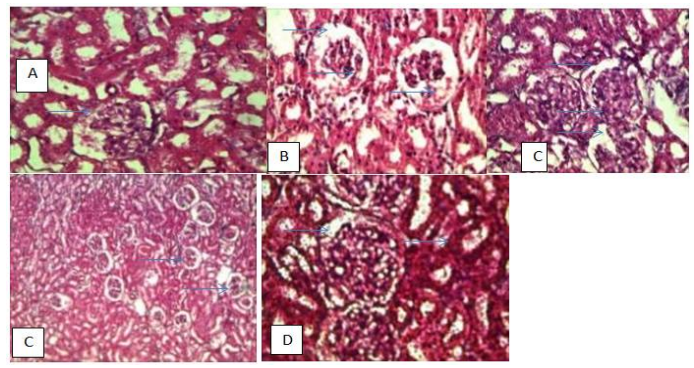

Figure 3: Photomicrograph of lung tissues showing the control with normal cellular architectures $(A)$, rats treated with $5 \mathrm{mg} B P A$ + pelleted rat feed+ water daily, showing cellular reduction in bowman capsule (B) (arrows), rats treated with $0.5 \mathrm{mg} /$ feed DEHP + pelleted rat feed+ water/day, showing reduction in bowman capsule and glomeruli (C). Rats treated with $0.5 \mathrm{mg} /$ feed BPA + 500 $\mu \mathrm{g} / \mathrm{kg}$ DEHP + water/daily (D) showing cellular reduction in bowman capsule (arrows). Stain H \& E; X400

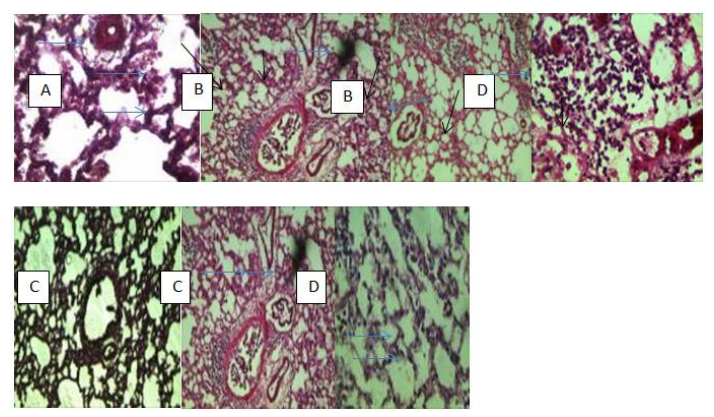

Figure 4: Photomicrograph of lung tissues showing the control with normal cellular architectures $(A)$, rats treated with $5 \mathrm{mg}$ BPA + pelleted rat feed+ water daily, showing evidence of infiltration of the alveoli, neutrophils and lymphocyte (B) (arrows), rats treated with $0.5 \mathrm{mg} /$ feed DEHP + pelleted rat feed+ water/day, showing infiltrations of neutrophils and lymphocytes, the alveoli and interstitium (C). Rats treated with $0.5 \mathrm{mg} /$ feed BPA $+500 \mu \mathrm{g} / \mathrm{kg} \mathrm{DEHP}+$ water/daily (D) showing infiltrations of neutrophils and lymphocytes, the alveoli and interstitium (arrows). Stain H \& E; X400

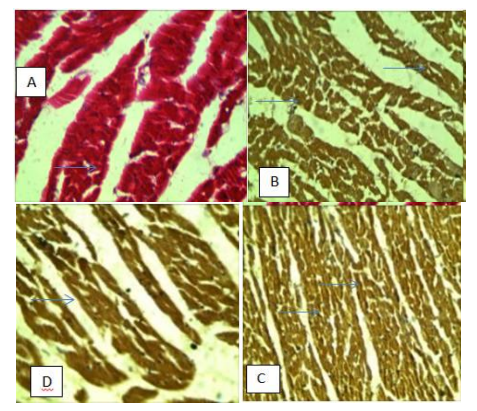

Figure 5: Photomicrograph of muscular tissues showing control with normal cellular architectures $(A)$, rats treated with $5 \mathrm{mg} /$ feed BPA + pelleted rat feed+ water daily (B) with normal cellular architecture as control, rats treated with $0.5 \mathrm{mg} / \mathrm{kg} \mathrm{DEHP}+$ pelleted rat feed + water/day $(C)$ and rats treated with $0.5 \mathrm{mg} / \mathrm{kg}$ $\mathrm{BPA}+500 \mu \mathrm{g} / \mathrm{kg} \mathrm{DEHP}+$ water/daily (D) also shows similarity with the control. stain H\&E; X400mag.

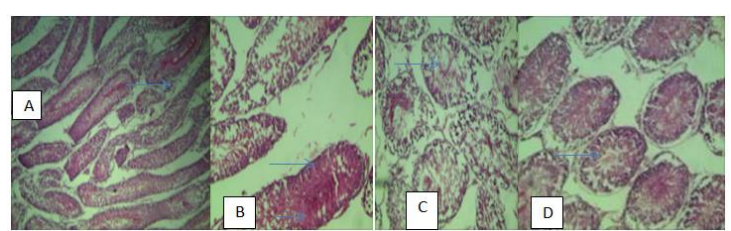

Figure 6: Photomicrograph of testicular tissues showing the control with normal cellular architectures (A), rats treated with $5 \mathrm{mg}$ BPA + pelleted rat feed+ water daily, showing evidence of reduction of leydig cells (B) (arrows), rats treated with $0.5 \mathrm{mg} /$ feed DEHP + pelleted rat feed+ water/day, reduction of leydig cells (B). Rats treated with $0.5 \mathrm{mg} /$ feed BPA $+500 \mu \mathrm{g} / \mathrm{kg}$ DEHP + water/daily (D) shows reduction in leydig cells (arrows). Stain H \& E; X400

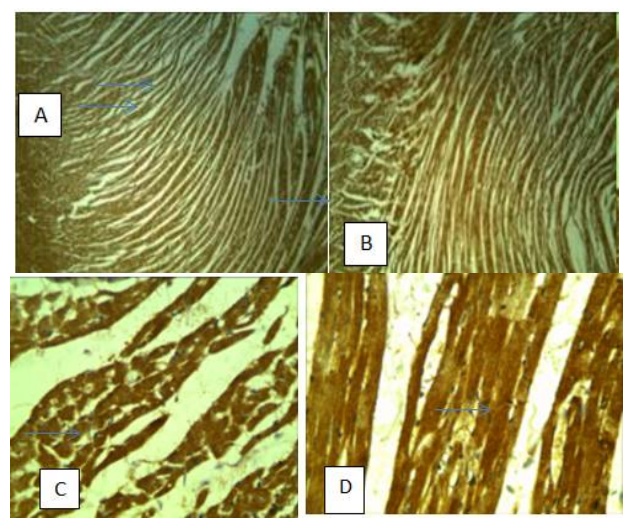

Figure 7: Photomicrograph of heart tissues showing control with normal cellular architectures $(A)$, rats treated with $5 \mathrm{mg} /$ feed BPA + pelleted rat feed+ water daily (B) with normal cellular architecture as control, rats treated with $0.5 \mathrm{mg} / \mathrm{kg}$ DEHP + pelleted rat feed + water/day $(\mathrm{C})$ and rats treated with $0.5 \mathrm{mg} / \mathrm{kg} \mathrm{BPA}+$ $500 \mu \mathrm{g} / \mathrm{kg}$ DEHP + water/daily (D) also shows similarity with the control. There is no evidence of an increase in Ki 67 activities

Table 1: Weight variations in treated rats versus control

\begin{tabular}{lcr}
\hline $\begin{array}{l}\text { Variable } \\
\text { Group III }\end{array}$ & $\begin{array}{c}\text { Group I } \\
\text { Group IV }\end{array}$ & Group II \\
\hline & $199.50 \pm 1.88$ & $181.00 \pm 5.51$ \\
$180.83 \pm 2.92^{*}$ & $160.58 \pm 1.78^{*}$ & \\
$P$-value & & 0.000 \\
0.000 & 0.000 & \\
\hline
\end{tabular}

Values are expressed as mean \pm standard deviation:

The sign $\left({ }^{*}\right)$ denote significant difference compared to control $(p \leq 0.05)$.

\section{DISCUSSION}

The body weight assessed in this study indicated a critical decrease in sizes probably resulting from BPA and DEHP administration, thereby hindering the growths of the animals. The decrease may be due to identified inhibitory properties of DEHP and BPA on specific hormones responsible for growth in mammals, 
which has been reported by notable authors $[12,13]$. The inflammation and stored fats as shown in sections of treated rats (BPA) were in consonance with the discoveries by Moon et al [14]. The discernible cellular infiltration and fat's deposit in hepatic cells may result from induced oxidative stress prompted by the treatment of BPA interactions in experimental rats [15]. The observed inflamed cells in addition to fatty deposits brought about by DEHP treatment in rats were not dissimilar to the cellular alterations brought about by BPA treatments that have been reported [16,17]. Bisephenol $A$ has been reported to have the capacity to inflict a severe hepatocellular destruction and mitochondrial incompetence resulting from increased oxidative stress within the hepatocytes [15]. The cellular changes of rat's liver treated with DEHP could be said to be dose-related due to rising degree of observed damages as the dosage is increased and is similar to observations that was recorded by Jassim et al [18].

Cell alteration is increasingly evident in rats administered BPA and DEHP combined therapy in compares with those treated with BPA and DEHP independently. The inflammatory effect of DEHP on the liver may be due in parts to the detoxifying role of the liver against chemical substances in the body [19]. Decreases in cellularity of glomeruli and bowman capsule in rats on BPA and DEHP treatments could have being as a result of the over burdens on the kidneys trying to filter and attempting to channel off injurious metabolites after breaking down BPA and DEHP to smaller molecules [20]. The swelling (edema) in the alveoli of the lungs in treatment groups (II to IV) could have resulted from blood infections arising from undue exposure of lungs to BPA and DEHP chemicals, which ultimately gives rise to pulmonary distresses [21,22]. It could also have resulted from lung damage or pulmonary infection from heavy metal accumulation from BPA and DEHP metabolites thereby preventing proper respiratory function of the lung.

The reduction in the legdig cells could lead to reduction in the testicular function [15].The rats treated with DEHP also reveals alteration in the liver, lung and leydig cells of the testes in increasing doses. This study showed no loss in cellularity in intestinal tissues and cardiac muscles pre-treated with BPA and DEHP which disagree with the findings of Robin et al [23]; in which treated female rats demonstrated a serious cardiomyopathy with diminished collagen muscle structures in the heart and was significant compared to controls. The reasons for these discrepancies may not be readily substantiated.
However, sample size may unravel the differences in observation. Recall that juvenile rats were used in both studies and thus require extra investigation to establish the causes behind the disparity both studies utilized a limited number of experimental animals.

\section{CONCLUSION}

The findings of the study show that both BPA and DEHP cause significant weight loss and could lead to deleterious effects and changes in the cellular make-up of rat tissues, including liver, kidney, lungs, and testicular tissues which may exact similar effects in humans. Furthermore, BPA and DEHP do not affect all organs of the rat body but only some.

\section{DECLARATIONS}

\section{Acknowledgement}

The authors wish to acknowledge the staff of Medical Laboratory Department, Histopathology Unit, University of Nigeria Teaching Hospital for help with tissue processing.

\section{Conflict of interest}

No conflict of interest is associated with this work.

\section{Contribution of authors}

We declare that this work was done by the authors named in this article and all liabilities pertaining to claims relating to the content of this article will be borne by the authors.

\section{Open Access}

This is an Open Access article that uses a funding model which does not charge readers or their institutions for access and distributed under the terms of the Creative Commons Attribution License (http://creativecommons.org/licenses/by/ 4.0) and the Budapest Open Access Initiative (http://www.budapestopenaccessinitiative.org/rea d), which permit unrestricted use, distribution, and reproduction in any medium, provided the original work is properly credited.

\section{REFERENCES}

1. Shin BS, Kim CH, Jun YS, Kim DH, Lee BM, Yoon $\mathrm{CH}$, Park EH, Lee K.C, Han SY, Park KL, et al. Physiologically based pharmacokinetics of bisphenol $A$. J Toxicol Environ Health A. 2004; 67: 1971-1985. 
2. Nunez AA, Kannan K, Giesy JP, Fang J, Clemens LG. Effects of bisphenol $A$ on energy balance and accumulation in brown adipose tissue in rats. Chemosphere. 2001; 42: 917-922.

3. Seidlova-Wuttke $D$, Jarry $H$, Christoffel J, Rimoldi G, Wuttke W. Effects of bisphenol-A (BPA), dibutylphtalate $(D B P)$, benzophenone-2 (BP2), procymidone (Proc), and linurone (Lin) on fat tissue, a variety of hormones and metabolic parameters: a 3 months comparison with effects of estradiol (E2) in ovariectomized (ovx) rats. Toxicology. 2005; 213: 13-24.

4. Sakurai K, Kawazuma M, Adachi T, Harigaya $T$, Saito $Y$, Hashimoto N, Mori C. Bisphenol A affects glucose transport in mouse 3T3-F442A adipocytes. $\mathrm{Br} J$ Pharmacol.2004; 141: 209-214.

5. Masuno H, Kidani T, Sekiya K, Sakayama K, Shiosaka T, Yamamoto H, Honda K. Bisphenol A in combination with insulin can accelerate the conversion of 3T3-L1 fibroblasts to adipocytes. J Lipid Res. 2002; 43: 676684.

6. Masuno H, Iwanami J, Kidani T, Sakayama K, Honda K. Bisphenol a accelerates terminal differentiation of 3T3$L 1$ cells into adipocytes through the phosphatidylinositol 3-kinase pathway. Toxicol Sci. 2005; 84: 319-327.

7. Scenihr $R$. Preliminary report on the safety of medical devices containing DEHP-plasticized PVC or other plasticizers on neonates and other groups possibly at risk. 2007; 82-44.

8. NIOSH. Manual of analytical method (NMAM). Di(2ethylhexyl)phthalate Method 5020. DHHS (NIOSH). Schelect PC O' Connol PC editor. Cincinnati oh. National Institute for Occupat Safety Health.2003; 151 . 154

9. Lorke DA. A new approach to practical acute toxicity testing. Arch Toxicol. 1983; 54:275-287.

10. Cheesbrough M. District Laboratory Practice in the Tropical countries part 2.(2nd ed.) Cambridge University Press.2006; pp 209-334.

11. Omorodion NT, Ajanwachuku WO. Investigation of Histopathological Effect of Piper nigrum Consumption on Selected Organ of Male Wistar Rats. Acta Sci. Nutrit. Health.2018; 23: 03-07.

12. Wittassek M, Angerer J. Phthalates: metabolism and exposure. Int. J. Androl. 2008; 31: 131-138.
13. Rehab M, Hussein, Jehane I. Eid. Pathological mechanisms of liver injury caused by oral administration of bisphenol A. Life Sci J 2013; 10 (1): 663-673.

14. Moon MK, Kim MJ, Jung IK, Koo YD, Ann HY, Lee KJ, Kim SH, Yoon YC, Cho BJ, Park KS, et al. Bisphenol A impairs mitochondrial function in the liver at doses below the no observed adverse effect level. J. Korean Med. Sci.2012; 27: 644-652

15. Mourad IM, Khadrawy YA. The sensitivity of Liver, Kidney and testis of rats to oxidative stress induced by different doses of Bisphenol A. Int. J. Life Sci. Pharma Rev. 2012; 2, 19-28.

16. Khalik AA, Nosseir N, Salah MK, Tawfik MK. Histological and Electron Microscopic Study of the Postulated Protective Role of Green Tea Against DEHP Liver Toxicity in Mice. Afr J Health Sci. 2007; 14: 19-36.

17. Shehata AS, El-Rehim Mohamed ZA, El-Haleem MRA, Samak MA. Effects of Exposure to Plasticizers Di-(2Ethylhexyl) Phthalate and Trioctyltrimellitate on the Histological Structure of Adult Male Albino Rats' Liver. J Clin Toxicol 2013; 3: 169.

18. Jassim MA., Alkalby M. Effect of Bisephenol $A$ on Thyroid, Liver and Testiscular functions in Adult male Rats. Bas. J. Vet.2015; 15(1):187-206.

19. Ikele CB, Mgbenka BO, Oluah NS. Histopathological Effects of Diethyl Phthalate on Clarias Gariepinus Juveniles. Animal Res. Int.(2011) 8(3): 1431-1438

20. Miura $Y$, Naito M, Ablake M, Terayama H., Shuang-Quin $Y$., Qu N., Cheng L, Suna S, Jitsunari F, Itoh M. Shortterm effects of di-(2-ethylhexyl)phthalate on testes, liver, kidney and pancrease in mice. Asian J. Androl.2012; 9: 199-205.

21. Azza SA, Ebtihal AA, Mohamed AA, Asmaa MA. Lung injury induced by Bisphenol $A$ : $A$ food contaminant, is ameliorated by selenium supplementation. J. pathoph. 2017; 2: 003.

22. Guo J, Han B, Qin L, Li B, You H. Pulmonary Toxicity and Adjuvant Effect of Di-(2-exylhexyl) Phthalate in Ovalbumin-Immunized BALB/CMice. PLoS One 2012; 7(6): 39008.

23. Robin G, Jessica AK, Scott MB. Effects of Bisphenol A on Incidence and 1 Severity of Cardiac Lesions in the NCTR2 Sprague-Dawley Rat: A CLARITY-BPA Study. bioRxiv. 2017;20(3); 70-78. 